Original Research Article

\title{
The effect of Ramipril and Telmisartan on blood pressure and insulin resistance in hypertensive patients
}

\author{
Vaibhav Watts ${ }^{1}$, Bhupinder Singh ${ }^{2 *}$, Jaswant Rai ${ }^{1}$
}

${ }^{1}$ Department of Pharmacology, Government Medical College, Amritsar, Punjab, India ${ }^{2}$ Department of Medicine, Government Medical College, Amritsar, Punjab, India

Received: 08 March 2019

Revised: 01 April 2019

Accepted: 03 May 2019

\section{*Correspondence to:}

Dr. Bhupinder Singh, Email: vaibhavwatts146@ gmail.com

Copyright: (C) the author(s), publisher and licensee Medip Academy. This is an openaccess article distributed under the terms of the Creative Commons Attribution NonCommercial License, which permits unrestricted noncommercial use, distribution, and reproduction in any medium, provided the original work is properly cited.

\begin{abstract}
Background: Angiotensin converting enzyme (ACE) inhibitors and Angiotensin II Receptor Blockers (ARBs) have become keystones of therapy for hypertension but there are very few studies where they have been compared with each other. This study attempted to compare the effect of Ramipril and Telmisartan on Blood Pressure and Insulin Resistance in Hypertensive patients (JNC 8).

Methods: An open label, randomized, prospective and comparative study of twelve- week duration was conducted on 60 patients of hypertension (JNC-8), with the collaboration of Department of Pharmacology and Department of Medicine, Government Medical College, Amritsar. Group A and B were given Telmisartan 40mg and Ramipril $2.5 \mathrm{mg}$ OD respectively. Blood Pressure was recorded on every visit, whereas, fasting plasma insulin and HOMA-IR values were recorded at the baseline and at the end of the study. Fasting blood sugar was done at 0,4 and 12 weeks.

Results: At the end of 12 weeks, a significant reduction in Systolic/Diastolic blood pressure was observed in group A with a drop of $~ 14 / 9 \mathrm{mmHg}(\mathrm{p}<0.001)$ and in group $B$ too, the fall of $\sim 11.6 / 7.2 \mathrm{mmHg}$ was significant $(p<0.001)$. However, in inter-group comparison only SBP difference was significant between two groups $(\mathrm{p}<0.05)$. Change in HOMA-IR value was also significant in both the groups $(\mathrm{p}<0.001)$. The inter-group difference for HOMA-IR between both the groups (A vs B) was also statistically significant $(\mathrm{p}<0.01)$.

Conclusions: Telmisartan $40 \mathrm{mg}$ OD was more effective than Ramipril $2.5 \mathrm{mg}$ OD in controlling the SBP and improving Insulin resistance at the end of 12 weeks.
\end{abstract}

Keywords: HOMA-IR, Hypertension, Ramipril, Telmisartan

\section{INTRODUCTION}

Hypertension is considered as a metabolic syndrome which affects many systems of the body and alters various biochemical parameters. ${ }^{1}$ It is defined as a systolic blood pressure (SBP) of $140 \mathrm{~mm} \mathrm{Hg}$ or more, or a diastolic blood pressure (DBP) of $90 \mathrm{~mm} \mathrm{Hg}$ or more or taking antihypertensive medication. ${ }^{2}$ Hypertension is responsible for at least $45 \%$ of deaths due to heart disease and $51 \%$ of deaths due to stroke. Estimates show that $16 \%$ of ischemic heart disease, $21 \%$ of peripheral vascular disease, $24 \%$ of acute MI and $29 \%$ of strokes in India are attributable to hypertension. ${ }^{3}$

It is a complex disorder that is influenced by genetic and environmental factors as well as their interactions. Physical inactivity, alcohol consumption, obesity and stress also play important roles in the development of hypertension.

Hypertension commonly occurs in conjunction with Insulin Resistance and other components of the Metabolic 
syndrome, both Hypertension and Insulin Resistance not only have similar pathophysiological pathways but also share common dietary and lifestyle risk factors. ${ }^{4}$

The excessive activation of Renin-Angiotensin System and resultant increased synthesis and release of Angiotensin II (with vasopressor action) has been strongly implicated in the pathogenesis of Essential Hypertension. ${ }^{5}$ While in Insulin resistance, impaired functioning of insulin leads to compensatory increase in insulin levels as well as increased blood glucose levels due to decreased GLUT4 expression. ${ }^{6}$ Among the antihypertensive drugs beta blockers and diuretics (thiazides and loop diuretics) can themselves cause hyperglycemia and impair lipid profile, but ARB's and ACE inhibitors have rather shown a modest positive effect on lipid profile and insulin resistance; also both the ACE inhibitors and ARBs have been compared with a placebo for their anti-hypertensive effects but there are very few studies where they have been compared with each other so, the present study was undertaken to study the effect of ramipril and telmisartan on blood pressure and insulin resistance in hypertensive patients. ${ }^{7}$

\section{METHODS}

\section{Study design}

The present study was a prospective, randomised, open label and comparative study. It was conducted in Pharmacology and Medicine Department of Government Medical College, Amritsar. After taking the written informed consent in their vernacular language, patients were recruited from the outpatient Department of Medicine of Guru Nanak Dev Hospital in GMC, Amritsar. The duration of study was 12 weeks. The approval of Institutional Ethics Committee, Government Medical College, Amritsar was taken before the start of study.

\section{Inclusion criteria}

Patients of age $\geq 18$ years of either sex with diagnosis of Hypertension (JNC-8) were recruited in the study.

\section{Exclusion criteria}

Age $<18$ years, any hypertensive emergency like malignant hypertension, pregnant, lactating and child bearing females, secondary hypertension, diabetes, hypothyroidism, bilateral renal artery stenosis, renal failure, significant renal disease, serum creatinine $>2$ $\mathrm{mg} / \mathrm{dl}$, significant liver disease, SGOT/SGPT $>2$ times the normal value, known hypersensitivity to ACE inhibitors or ARBs, subjects on other anti-hypertensive, chronic steroid or hormone therapy

\section{Study participants}

The 60 Non-Diabetic Hypertensive (JNC-8) patients who fulfilled the inclusion criteria of protocol were randomised into 2 groups A and B consisting of 30 patients each. Renal function Tests (RFT) were done of all the patients for screening purposes. Patients with Blood urea and Serum Creatinine in normal range were included.

Group A was given Telmisartan $40 \mathrm{mg}$ once a day whereas group B received Ramipril $2.5 \mathrm{mg}$ once a day. Blood Pressure was recorded on every visit, whereas, fasting plasma insulin and HOMA-IR values were recorded at the baseline and at the end of the study i.e. 12 weeks. Fasting blood sugar was done at 0,4 and 12 weeks. The patients were instructed to fast 12 hours before testing was done. The data generated was evaluated and expressed as Mean \pm SD of each variable. The normality of the data was checked using the Kolmogorov-Smirnov test and the data was found to be normally distributed. Statistical tests were applied with the help of softwares Graphpad InStat 3 and IBM software SPSS-21.0 (Statistical Package for the Social Sciences). Paired Student's 't' test within the group after treatment interval and unpaired ' $t$ ' test was applied when 2 groups were compared. HOMA-IR was calculated by the formula- HOMA-IR=Fasting blood sugar $\mathrm{x}$ Fasting serum Insulin /405 (where FBG is in $\mathrm{mg} / \mathrm{dl}$ and FPI in $\mu \mathrm{U} / \mathrm{ml})$

\section{RESULTS}

Total 60 patients were enrolled in the study randomly divided into two groups- group A $(n=30)$ and group B $(n=30)$. The study drug groups were similar with respect to all the baseline features at 0 week (Table 1).

Table 1: Baseline characteristics of the participants in the study. (All values are expressed in Mean \pm SD).

\begin{tabular}{|lll|}
\hline Characteristics & $\begin{array}{l}\text { Group A- } \\
\text { Telmisartan }\end{array}$ & $\begin{array}{l}\text { Group B- } \\
\text { Ramipril }\end{array}$ \\
\hline No. of patients & 30 & 30 \\
\hline Age (years) & $47.87 \pm 9.35$ & $46.60 \pm 8.17$ \\
\hline Sex $(\mathrm{M}: \mathrm{F})$ & $15: 15$ & $18: 12$ \\
\hline SBP $(\mathrm{mmHg})$ & $150.27 \pm 7.57$ & $149.73 \pm 8.89$ \\
\hline DBP $(\mathrm{mmHg})$ & $91.07 \pm 7.62$ & $90.47 \pm 5.58$ \\
\hline FBG $(\mathrm{mg} / \mathrm{dL})$ & $108.35 \pm 17.63$ & $104.77 \pm 11.58$ \\
\hline FPI $(\mu \mathrm{U} / \mathrm{ml})$ & $9.51 \pm 1.33$ & $9.21 \pm 1.18$ \\
\hline HOMA-IR & $2.54 \pm 0.54$ & $2.38 \pm 0.40$ \\
\hline
\end{tabular}

In the present study, the maximum fall in Systolic Blood Pressure (SBP) was seen from 8 week to 12 weeks for group A and from 4 weeks to 8 weeks for group B; for Diastolic Blood Pressure (DBP) the maximum fall in both groups was seen from 4 weeks to 8 weeks.

All the changes in blood pressure (both SBP and DBP) readings were significant in both groups except for the DBP fall in Group A from 2 weeks to 4 weeks (Table 2).

Significant improvement in both systolic and diastolic blood pressure was seen in both groups. However, in intergroup comparison, SBP difference was significant 
between two groups; whereas DBP difference wasn't.

(Table 3, Table 4 and Figure 1).

Table 2: Intra Group comparison of progressive BP control in study period. (All values are expressed in Mean \pm SD).

\begin{tabular}{|c|c|c|c|c|c|c|c|}
\hline \multirow{2}{*}{$\begin{array}{l}\text { Time period } \\
\text { (wks) }\end{array}$} & \multirow{2}{*}{$\begin{array}{l}\text { BP } \\
(\mathrm{mmHg})\end{array}$} & \multicolumn{3}{|c|}{ Group A- Telmisartan } & \multicolumn{3}{|c|}{ Group B- Ramipril } \\
\hline & & Mean \pm SD & Mean change & P value & Mean \pm SD & Mean change & $P$ value \\
\hline \multirow{2}{*}{0} & SBP & $150.27 \pm 7.57$ & & & $149.73 \pm 8.89$ & & \\
\hline & DBP & $91.03 \pm 7.62$ & & & $90.47 \pm 5.58$ & & \\
\hline \multirow{2}{*}{2} & SBP & $146.67 \pm 6.02$ & -3.60 & $\mathrm{p}<0.001 * * *$ & $147.40 \pm 7.39$ & -2.33 & $\mathrm{p}<0.001 * * *$ \\
\hline & DBP & $88.13 \pm 6.12$ & -2.93 & $\mathrm{p}<0.001 * * *$ & $89.13 \pm 5.45$ & -1.33 & $\mathrm{p}<0.05^{*}$ \\
\hline \multirow{2}{*}{4} & SBP & $145.13 \pm 5.30$ & -1.53 & $\mathrm{p}<0.05^{*}$ & $144.80 \pm 6.84$ & -2.60 & $\mathrm{p}<0.001 * * *$ \\
\hline & DBP & $86.87 \pm 5.70$ & -1.26 & $\mathrm{p}=0.05$ & $87.20 \pm 5.05$ & -1.93 & $\mathrm{p}<0.001 * * *$ \\
\hline \multirow{2}{*}{8} & SBP & $141.07 \pm 4.42$ & -4.06 & $\mathrm{p}<0.001 * * *$ & $141.07 \pm 6.10$ & -3.73 & $\mathrm{p}<0.001 * * *$ \\
\hline & DBP & $83.93 \pm 5.13$ & -2.94 & $\mathrm{p}<0.001 * * *$ & $85.07 \pm 4.54$ & -2.13 & $\mathrm{p}<0.001 * * *$ \\
\hline \multirow{2}{*}{12} & SBP & $36.07 \pm 4.28$ & -5.00 & $\mathrm{p}<0.001 * * *$ & $138.07 \pm 6.07$ & -3.00 & $\mathrm{p}<0.001 * * *$ \\
\hline & DBP & $82.07 \pm 4.86$ & -1.86 & $\mathrm{p}<0.001 * * *$ & $83.20 \pm 4.54$ & -1.86 & $\mathrm{p}<0.001 * * *$ \\
\hline
\end{tabular}

Table 3: Changes in BP from 0 week to 12 weeks.

\begin{tabular}{|llllll|}
\hline \multirow{2}{*}{$\begin{array}{l}\text { Group } \\
\text { Time period }\end{array}$} & A- Telmisartan & & B- Ramipril & DBP $(\mathbf{m m} \mathbf{H g})$ \\
\cline { 2 - 6 } (weeks) & 0 & $150.27 \pm 7.57$ & $91.07 \pm 7.62$ & $149.73 \pm 8.89$ & $90.47 \pm 5.58$ \\
\hline Mean change & 12 & $136.07 \pm 4.28$ & $82.07 \pm 4.86$ & $138.07 \pm 6.07$ & $83.20 \pm 4.54$ \\
\hline \% change & -14.2 & -9 & -11.66 & -7.27 & 8.03 \\
\hline P value & 9.44 & 9.88 & 7.78 & $<0.001 * * *$ & $<0.001 * * *$ \\
\hline
\end{tabular}

“*” $\mathrm{p}<0.05$ - significant, “**” $\mathrm{p}<0.01$ - very significant; “***” $\mathrm{p}<0.001$ highly significant

Table 4: Blood pressure control with telmisartan vs ramipril.

\begin{tabular}{|lll|}
\hline \multirow{2}{*}{ Test value } & \multicolumn{3}{l|}{ BP control with drug A vs B } \\
& SBP & DBP \\
\hline P value & $\mathrm{p}<0.05^{*}$ & $\mathrm{p}>0.05$ \\
\hline
\end{tabular}

At the end of 12 weeks there was $\sim 9 \%$ reduction in FBG and $\sim 11 \%$ reduction in FPI in group A- Telmisartan; whereas group B-Ramipril showed $\sim 3 \%$ reduction in FBG and $\sim 3 \%$ reduction in FPI. (Table 5).
Table 6: Insulin resistance at 0 and 12 weeks. (All values are expressed in Mean $\pm \mathrm{SD})$.

\begin{tabular}{|llll|}
\hline Group & \multicolumn{3}{l|}{ HOMA-IR values } \\
& & A- Telmisartan & B- Ramipril \\
\hline Time period & 0 & $2.54 \pm 0.54$ & $2.38 \pm 0.40$ \\
\cline { 2 - 4 } (weeks) & 12 & $2.06 \pm 0.30$ & $2.24 \pm 0.35$ \\
\hline Mean change & -0.48 & -0.14 \\
\hline \% change & 18.9 & 5.9 \\
\hline P value & $<0.001 * * *$ & $<0.001 * * *$ \\
\hline “*” $\mathrm{p}<0.05$ - significant, “**” $\mathrm{p}<0.01$ - very significant; “***” $\mathrm{p}$ \\
$<0.001$ highly significant
\end{tabular}

Table 5: Changes in Fasting Blood Glucose (FBG) and Fasting Plasma Insulin (FPI) at 0 and 12 weeks. (All values are expressed in Mean \pm SD).

\begin{tabular}{|c|c|c|c|c|c|}
\hline & & \multicolumn{2}{|l|}{ FBG (mg/dL) } & \multicolumn{2}{|c|}{ FPI ( $\mu \mathrm{U} / \mathrm{ml})$} \\
\hline & & $\mathbf{A}$ & B & $\mathbf{A}$ & B \\
\hline \multirow{2}{*}{ Time period (weeks) } & 0 & $108.35 \pm 17.63$ & $104.77 \pm 11.58$ & $9.51 \pm 1.33$ & $9.21 \pm 1.18$ \\
\hline & 12 & $98.87 \pm 11.42$ & $101.67 \pm 8.99$ & $8.47 \pm 0.87$ & $8.91 \pm 1.15$ \\
\hline Mean change & & -9.48 & -3.10 & -1.04 & -0.3 \\
\hline$\%$ change & & 8.74 & 2.95 & 10.9 & 3.25 \\
\hline
\end{tabular}

“*” $\mathrm{p}<0.05$ - significant, “**” $\mathrm{p}<0.01$ - very significant; “***” $\mathrm{p}<0.001$ highly significant 
Decrease in HOMA-IR value in two groups was significant at 12 weeks. Telmisartan caused a $\sim 19 \%$ reduction in HOMA-IR while Ramipril showed $\sim 6 \%$ reduction. However, the intergroup difference between the both groups (A vs B) was also statistically significant (p<0.01). (Table 6, Table 7 and Figure 2).

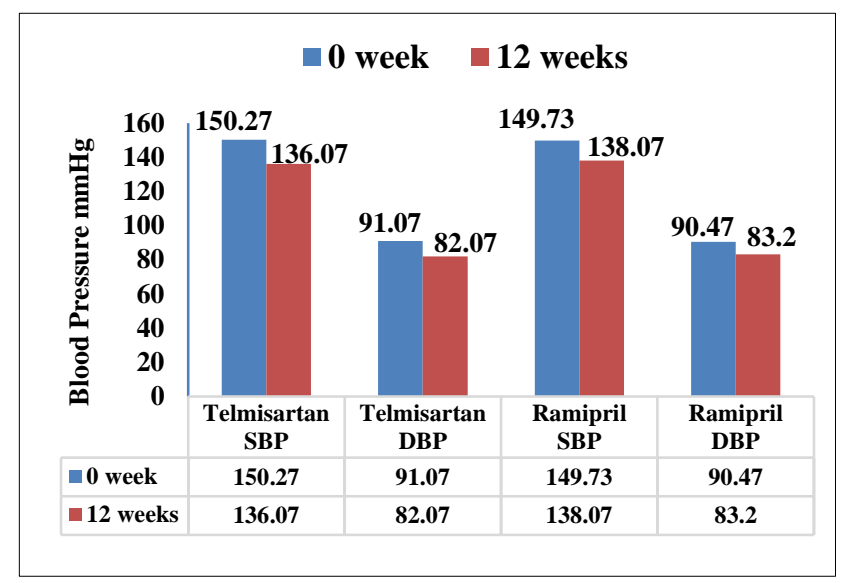

Figure 1: Decrease in blood pressure with study groups from 0 week to $12^{\text {th }}$ week.

Table 7: Changes in HOMA-IR values with Telmisartan vs Ramipril.

\begin{tabular}{|ll|}
\hline Test value & $\begin{array}{l}\text { Effect on HOMA-IR values in } \\
\text { Group A vs B }\end{array}$ \\
\hline P value & $<0.01 * *$ \\
\hline
\end{tabular}

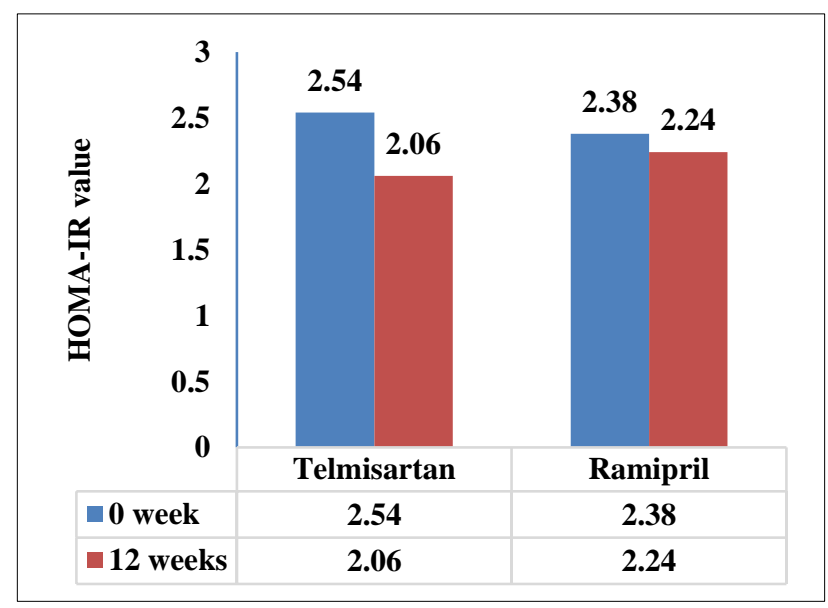

Figure 2: Insulin resistance at 0 and 12 weeks.

\section{DISCUSSION}

In the present study 60 non-diabetic hypertensive patients were recruited following the inclusion criteria. The mean age of the patients was $47.23 \pm 8.73$ years, sex distribution of male: female was 11:9 (55\%:45\%). The baseline characteristics were comparable at the beginning of the study in both the groups ( $p>0.05)$ (Table 1).

\section{Effect on blood pressure}

All the changes in blood pressure (both SBP and DBP) readings were significant in both groups except for the DBP fall in Group A from 2 weeks to 4 weeks.

SBP decreased by $\sim 9.4 \%$ and $7.8 \%$ respectively in both the groups $(\mathrm{p}<0.001)$ and fall in DBP was $\sim 9.8 \%$ and $8 \%$ in both groups respectively $(\mathrm{p}<0.001)$.

With Telmisartan, a mean fall in SBP and DBP from the baseline $(150.27 \pm 7.57$ and $91.07 \pm 7.62)$ was $\sim 14 \mathrm{mmHg}$ and $9 \mathrm{mmHg}$ respectively after 12 weeks of treatment in the present study, where the dose of Telmisartan used was $40 \mathrm{mg}$ once a day. Plavnik et al reported a mean fall to be $14.4 \mathrm{mmHg}$ for SBP and $10.3 \mathrm{mmHg}$ for DBP $(\mathrm{p}<0.05)$ after 12 weeks of Telmisartan treatment. ${ }^{7}$ However, in this study, Telmisartan $40 \mathrm{mg} /$ daily was given for 6 weeks. In those patients whose blood pressure BP levels were lower than $140 / 90 \mathrm{mmHg}$, the same dosage was kept for an additional period of 6 weeks. For those who had BP higher than $140 / 90 \mathrm{mmHg}$, the dosage was increased to 80 $\mathrm{mg} /$ daily.

Another study of 14 weeks duration done by Yves Lacourcière et al, on behalf of the PRISMA II Investigators, Telmisartan $40 \mathrm{mg} /$ daily was given for first two weeks; followed by dose $80 \mathrm{mg}$ /daily for remaining 12 weeks. $^{8}$ The mean fall in SBP/DBP was $13.7 / 10.3 \mathrm{mmHg}$ and $14.3 / 11 \mathrm{mmHg}(\mathrm{p}<0.001)$ at the end of 8 weeks and 14 weeks respectively.

With Ramipril, the mean change in SBP and DBP from the baseline (149.73 \pm 8.89 and $90.47 \pm 5.58)$ was observed to be 11.6 and $7.2 \mathrm{mmHg}$ respectively by the end of the present study (12 weeks) with dose $2.5 \mathrm{mg}$ daily; while a mean fall of $30.12 \mathrm{mmHg}$ in SBP and $13.8 \mathrm{mmHg}$ in DBP was reported by Mustafa Raja et al, after using Ramipril $5 \mathrm{mg}$ daily for 12 weeks. ${ }^{9}$

However, in the inter-group comparison for BP lowering in group A and B (Table 4), SBP difference was significant $(p<0.05)$ whereas the DBP difference wasn't significant $(\mathrm{p}>0.05)$.

Yves Lacourcière et al, in a 14 week study reported that Telmisartan $80 \mathrm{mg}$ was consistently more effective than Ramipril $10 \mathrm{mg}$ in reducing both DBP and SBP. ${ }^{8}$

\section{Effect on HOMA-IR}

\section{Fasting blood glucose}

In group A (Telmisartan) mean fall in FBG was $~ 9.4$ $\mathrm{mg} / \mathrm{dL}(8.7 \%)$ from initial baseline of $108.35 \pm 17.63$ $\mathrm{mg} / \mathrm{dL}(\mathrm{p}<0.001)$, the results were consistent with Tripathi $\mathrm{N}$ et al who reported a mean fall of $11.53 \mathrm{mg} / \mathrm{dL}(10 \%)$ from initial baseline of $112.23 \pm 20.41 \mathrm{mg} / \mathrm{dL}(\mathrm{p}<0.01)$ (Table 5). ${ }^{9}$ 
In group B (Ramipril), the fall was $3.10 \mathrm{mg} / \mathrm{dL}(\sim 3 \%)$ from initial baseline of $104.77 \pm 11.58 \mathrm{mg} / \mathrm{dL} \quad(\mathrm{p}<0.001)$, whereas Salve PS et al reported a mean fall of $\sim 3 \mathrm{mg} / \mathrm{dL}$ $(3.7 \%)$ from the initial baseline of $79.37 \pm 8.34 \mathrm{mg} / \mathrm{dL}$ $(\mathrm{p}<0.01)$ which was almost equivalent to that observed in the present study. ${ }^{1}$

\section{Fasting plasma insulin (Table 5)}

In group A, after 12 weeks of treatment, mean fall in FPI was $1.04 \mu \mathrm{U} / \mathrm{ml}(\sim 11 \%)$ from baseline value of $9.51 \pm 1.33$ $\mu \mathrm{U} / \mathrm{ml}(\mathrm{p}<0.001)$ whereas Miura et al10 after 12 weeks of study reported a $2.1 \mu \mathrm{U} / \mathrm{ml}$ fall in FPI, from the initial baseline of $10.7 \pm 3.8(\mathrm{p}<0.01)$.

With Ramipril the mean fall in FPI is $0.3 \mu \mathrm{U} / \mathrm{ml}(\sim 3 \%)$ from the initial baseline value of $9.21 \pm 1.18 \mu \mathrm{U} / \mathrm{ml}$ $(\mathrm{p}<0.05)$, whereas KS Podila et al reported a mean fall of $0.54 \mu \mathrm{U} / \mathrm{ml}$ from the baseline value of $12.7 \pm 5.47$ in a 24 week study. ${ }^{11}$

\section{Insulin resistance (HOMA-IR values)}

HOMA-IR values at 0 week in group A and group B were $2.54 \pm 0.54$ and $2.38 \pm 0.40$ respectively (Table 6).

In group A (Telmisartan), after 12 weeks of treatment, the mean change in HOMA-IR value was a drop by 0.48 molar units $(\sim 19 \%)$ from the baseline value $(p<0.01)$. Fall in HOMA-IR as seen by Luis et al12 was 1.01 (molar units). In another study by Cioni et al, there was a similar fall in HOMA-IR i.e. 1.0 (molar units) after 16 weeks of therapy. ${ }^{13}$ The fall is less in this study; one reason can be the patient pool which also comprised of the patients who were already taking Telmisartan for hypertension before entering the study.

With Ramipril (group B), the mean change in HOMA-IR after 12 weeks was a fall of 0.14 (molar units) which is $\sim 6 \%$ from the baseline value $(\mathrm{p}<0.01)$, whereas KS Podila et al reported a mean fall of 0.31 (molar units) from the baseline value of $3.2 \pm 1.51$, with the study duration being 24 weeks and dose of Ramipril used was $5 \mathrm{mg}$ daily. ${ }^{11}$

However, the intergroup difference between the both groups (Table 7, Figure 2) (Telmisartan vs Ramipril) for HOMA-IR value was also statistically significant $(\mathrm{p}<0.01 * *)$.

\section{CONCLUSION}

Although both the drugs showed significant results, Telmisartan $40 \mathrm{mg}$ OD was consistently more effective and superior to Ramipril $2.5 \mathrm{mg}$ OD in controlling the SBP and improving Insulin resistance in non-diabetic hypertensive patients at the end of 12 weeks. Both drugs were well tolerated. Though this study had few limitations with respect to small sample size and single centric study, further studies can be done to look for the various beneficial effects of both Telmisartan and Ramipril.

\section{ACKNOWLEDGEMENTS}

Authors would like to thank Department of Medicine, Guru Nanak Dev Hospital, Amitsar, Punjab, India.

Funding: No funding sources

Conflict of interest: None declared

Ethical approval: The study was approved by the Institutional Ethics Committee

\section{REFERENCES}

1. Salve PS, Khanwelkar CC, Salve PS, Thorat VM, Matule SM. Effects of angiotensin converting enzyme inhibitor: ramipril on different biochemical parameters in essential hypertensive patients. Int J Res Med Sci. 2017 Jan 2;4(6):2288-91.

2. Writing Group Members, Mozaffarian D, Benjamin EJ, Go AS, Arnett DK, Blaha MJ, et al. Heart Disease and Stroke Statistics-2016 Update: A Report from the American Heart Association. Circulation. 2016 Jan 26;133(4):e38-360.

3. Benjamin EJ, Blaha MJ, Chiuve SE, Cushman M, Das SR, de Ferranti SD, et al. Heart Disease and Stroke Statistics-2017 Update: A Report from the American Heart Association. Circulation. 2017;135(10):e146e603.

4. Beale EG. Insulin Signaling and Insulin Resistance. J Investig Med Off Publ Am Fed Clin Res. 2013 Jan;61(1):11-4.

5. Manrique C, Lastra G, Gardner M, Sowers JR. The Renin Angiotensin Aldosterone System in Hypertension: Roles of Insulin Resistance and Oxidative Stress. Med Clin North Am. 2009 May;93(3):569-82.

6. Wilcox G. Insulin and Insulin Resistance. Clin Biochem Rev. 2005 May;26(2):19-39.

7. Plavnik FL, Ribeiro AB. A multicenter, open-label study of the efficacy and safety of telmisartan in mild to moderate hypertensive patients. Arq Bras Cardiol. 2002 Oct;79(4):339-50.

8. Lacourcière Y, Neutel JM, Davidai G, Koval S. A multicenter, 14-week study of telmisartan and ramipril in patients with mild-to-moderate hypertension using ambulatory blood pressure monitoring. Am J Hypertens. 2006 Jan;19(1):104-12.

9. Tripathy JP, Thakur JS, Jeet G, Chawla S, Jain S. Alarmingly high prevalence of hypertension and prehypertension in North India-results from a large crosssectional STEPS survey. PLoS ONE [Internet]. 2017 Dec 21;12(12):e0188619.

10. Miura Y, Yamamoto N, Tsunekawa S, Taguchi S, Eguchi Y, Ozaki N, et al. Replacement of valsartan and candesartan by telmisartan in hypertensive patients with type 2 diabetes: metabolic and antiatherogenic consequences. Diabetes Care. 2005 Mar;28(3):757-8.

11. Podila KS, Pathapati R, Sreebhushanraju, Vijayalakshmi K, Ramesh V. A Comparative Study to Evaluate the Effect of Ramipril and Telmisartan on the 
Components of Metabolic Syndrome in Chronic Kidney Disease Patients. Int J Pharm and Biological Sci. 2014 Apr-June;4(2):122-7.

12. de Luis DA, Conde R, González-Sagrado M, Aller R, Izaola $\mathrm{O}$, Dueñas $\mathrm{A}$, et al. Effects of telmisartan vs olmesartan on metabolic parameters, insulin resistance and adipocytokines in hypertensive obese patients. Nutr Hosp. 2010 Apr;25(2):275-9.
13. Rivara MB, Mehrotra R. New-Onset Diabetes in Peritoneal Dialysis Patients - Which Predictors Really Matter? Perit Dial Int J Int Soc Perit Dial. 2016;36(3):243-6.

Cite this article as: Watts V, Singh B, Rai J. The effect of Ramipril and Telmisartan on blood pressure and insulin resistance in hypertensive patients. Int $\mathbf{J}$ Basic Clin Pharmacol 2019;8:1262-7. 